\title{
Development Strategy of Bank Insurance Based on Financial Mixed Operation
}

\author{
Xiaobing Jiang \\ Dongfang College, Shandong University of Finance and Economics, Taian, China
}

122666860@qq.com

Keywords: bank insurance; policy suggestions; mode selection

\begin{abstract}
For promoting the sustainable development of China's bank insurance, this research started from the theoretical study of bank insurance and based on a thorough analysis of foreign bank insurance, summarized the experience of bank insurance development in developed countries, combined with the development status of China's bank insurance, and the problems and its causes in the process were thoroughly analyzed and discussed. A series of specific countermeasures and suggestions were proposed for the development of China's bank insurance, including the choice of bank insurance model, the formulation of the banking insurance institution's strategy, and related policy recommendations. It was in line with the development needs of China's bank insurance.
\end{abstract}

\section{Introduction}

Since the 1980s, the world's financial powers have abandoned the traditional separation system and began to transition to a mixed industry system. The wave of financial globalization and liberalization has greatly changed the competitive landscape and situation of the financial industry. Banks and insurance companies have begun to adopt a strategy of mutual integration and penetration, and bank insurance has thus emerged. With the continuous deepening of financial integration, bank insurance has become an important trend in the development of the global financial industry.

The development of bank insurance has far-reaching strategic significance for Chinese commercial banks and insurance companies. From the perspective of commercial banks, bank insurance not only brings considerable fee income to commercial banks, but more importantly it is beneficial to the strategic transformation of commercial banks. From the perspective of insurance companies, bank insurance is one of the three pillars of life insurance and has become a major force for life insurance business growth. Obviously, it is of great significance for the Chinese insurance industry to achieve the strategic goal of "bigger and stronger". In the face of numerous opportunities and challenges, the development of the Bank of China Insurance must proceed from the current reality of separate operations and supervision of separate industries. On the one hand, it solves the problems existing in the development of bank insurance, and on the other hand, it adapts to the future trend of comprehensive management, seriously absorbs and draws lessons from the development of international banking insurance, solves the deep-seated problems in the development of bank insurance through model innovation, strategic innovation, and institutional innovation to form a bank insurance market with Chinese characteristics.

This research will start with the theoretical analysis and summarize the experiences in the development of foreign bank insurance. Based on a comprehensive analysis of the problems and the causes of the development of China's bank insurance, the paper puts forward suggestions for promoting the further development of China's bank insurance.

\section{Literature review}

With regard to the definition of bank insurance, various scholars have conducted a full range of discussions. Some scholars in the United States have defined bank insurance as an organization that crosses shares held by banks or their branches, banks and insurance companies, operates insurance products with asset management functions, cross-markets, or sells any products that banks and 
insurance products can bring or service [1]. According to Munich Re Group in a 2001 report "Bank Insurance in Practice", bank insurance refers to provide insurance and banking products and services to the same group of customers at the same time through a common sales channel [2]. The traditional view emphasizes the dissimilarity between the banking industry and the insurance industry. It points out that although both belong to the financial industry field, they do not have similarities and can't be integrated [3]. Chinese scholars believe that bank insurance, also known as bancassurance, is a financial services integration arrangement between banks and insurance companies. Among them, insurance companies are responsible for the manufacture of products, and banks are responsible for the sale of products [4]. Domestic scholars have summarized the development model of bank insurance according to different organizational models or operating characteristics in the development of bank insurance, and proposed suggestions for the development of bank insurance in China in light of the actual situation [5]. The success of the western banking insurance industry is inseparable from a good external environment. In contrast, the external environment for the development of China's banking insurance needs to be further improved [6].

\section{Methodology}

\subsection{Theoretical dialysis of bank insurance}

Bank insurance began in Europe and gradually flourished in the 1980s. Daniel divides the development of bank insurance into three phases. Prior to 1980, as the first phase, bank insurance was limited to banks acting as intermediaries for insurance companies; the second phase started in about 1980, bank began to develop products that are very different from traditional banking businesses and began to fully intervene in the insurance area. This is considered to be the real beginning of bank insurance. In the late 1980s, it began to enter the third phase, which is a crucial period for the development of bank insurance. In order to cope with the fierce competition of insurance companies, banks also expanded the business in this period and adopted various measures (such as new establishments, mergers and acquisitions, joint ventures, etc.) to combine banking services with insurance business.

The birth and development of bank insurance come from the choice of the main business entity in the micro field, and also from the changes in the external environment of the macro field. Bank insurance is a realistic option for commercial banks to structure a diversified business structure and create a versatile financial group. For insurance companies, it is an effective way to expand marketing channels and increase operating income. Banks and insurance companies have achieved a win-win result from the launch of the bank's insurance business, which provides an intrinsic motivation for the mutual penetration of both parties. After the entire economy has reached a certain stage, various external influence factors have directly or indirectly led to the integration of banks and insurance companies and promoted the emergence and development of bank insurance, including: aging of the population, changes in consumer awareness, obvious trends in comprehensive operations, and technological advances.

\subsection{Analysis of the development of bank insurance in China}

At present, the effectiveness of the insurance regulatory department in implementing structural adjustment policies has further manifested, and the business cooperation of bank insurance has also changed. The insurance industry has begun to treat the banking insurance business soberly, and the banking industry has also begun to study the issue of the depth of cooperation between the bank and the insurance industry. In the past, the bank insurance mainly focused on payment of products, and the increase in the sales volume of the payment products would inevitably reduce the current premium income, but it would be conducive to the formation of continuous premium income. At the same time, due to the great homogeneity of insurance products sold on the bank's windows and other wealth management products, tailored insurance products with strong individualization are difficult to sell through the bank's window, in addition, the cooperation between banks and the insurance industry is no longer satisfied with the simple agency cooperation model. Therefore, on 
the basis of actively adjusting the structure, the insurance industry and the banking industry have begun to explore ways to develop long-term, in-depth, and stable cooperation. The insurance industry began to gradually adjust its business structure, focusing on the development of payment-oriented and guaranteed products. At present, the bank insurance business is in a stage of vigorous development in China and presents several characteristics: Bank insurance develops rapidly, especially in the life insurance sector, it has become the second largest sales channel, the development of non-life insurance is relatively inadequate, and the premium income of China's bank insurance has been increasing year after year. It has become an important part of China's insurance market; the agency agreement model still dominates, but new models such as joint ventures and equity investments begin to emerge; the development of bank insurance is restricted by the financial system under separate management and supervision; commercial banks have the natural advantage of selling insurance products. Vigorously developing China's bank insurance can enhance the profitability of commercial banks, promote the steady development of the insurance industry, and realize the beneficial attempts of mixed-business operations.

\subsection{Problems and causes of the development of bank insurance in China}

At present, there are problems in the development of China's bank insurance: the relationship between the two sides is loose, and the cooperation model is simple; bank insurance products are single with high homogeneity; the sales method is simple and the sales channel is simple; the operating cost is too high and the cost competition is fierce; marketing and promotion is one-sided, and misleading sales have seriously affected the credit rating of the Bank of China. The main causes of these problems are: there is a deviation in the understanding between the two sides, and the business philosophy is old; there is a big difference in the corporate culture between the two sides; insufficient cooperation and development of new products and new channels between the two parties; lack of effective incentive and restraint mechanisms; lack of compound professionals and difficulty in improving service levels; the backward information technology means affect the efficiency of business processing; external environmental constraints.

\section{Results}

\subsection{The model choice of China's bank insurance}

China's current development of bank insurance generally adopts a distribution agreement model, because of its own inherent defects, it brings a series of problems that can't be ignored to the development of bank insurance, and it becomes a bottleneck that restricts the further and rapid development of bank insurance. To overcome this bottleneck, we need to make a new choice of development model. In various development models, although the joint venture model and the financial group model have begun to appear, due to the difficulties in implementation, they are not yet suitable for universal promotion. And strategic alliance model can make up for the shortcomings of distribution agreement mode, at the same time, it is more suitable for the economic development of China's current reality, so it can be used as the bank insurance generally used at the present stage in China's business model. The strategic alliance model is the best business model for the development of bank insurance in our country at this stage, the development of China's bank insurance should shift from the original loose distribution agreement model to the closely-coordinated strategic alliance model. Establishing the "1+1" exclusive strategic alliance model is the key to the current development of bank insurance, firstly, the establishment of a strategic alliance model should be promoted in stages and at different levels; then, carefully select strategic partners and establish long-term strategic partnerships; finally, take advantage of some success stories. 


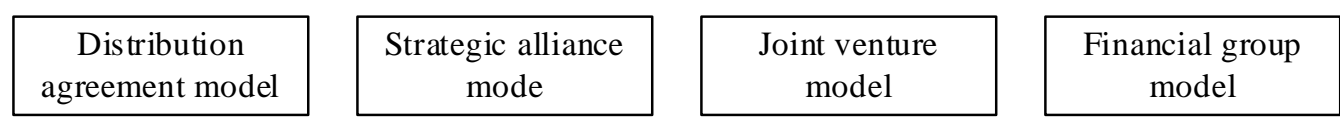

The degree of integration of bank insurance has gradually deepened

\begin{tabular}{|c|}
\hline \\
As a part-time \\
agent, banks sell \\
insurance products \\
and obtain income \\
from handling \\
fees; There is no \\
or little sharing of \\
customer \\
resources; Both \\
sides lack the \\
necessary \\
investment.
\end{tabular}

\begin{tabular}{|c|}
\hline The integration of \\
product \\
development and \\
service delivery \\
and channel \\
management has \\
begun to merge; \\
May make a \\
difference in \\
sharing customer \\
information; \\
Increase \\
investment in the \\
training of IT and \\
sales \\
Commissioners. \\
\hline
\end{tabular}

\begin{tabular}{|l|}
\hline \\
Give full play to \\
the advantages of \\
their products and \\
customers; \\
Realizing the \\
integration of bank \\
insurance within \\
the enterprise; \\
The two sides set \\
up a long-term \\
cooperative \\
relationship. \\
\end{tabular}

High integration of
business and
system; Have a
strong
development
bank's existing
customer
capability;
Providing "one-
stop" service to
customers; The
potential to
provide highly
integrated
products.

Figure. 1 The basic mode and characteristics of the bank insurance.

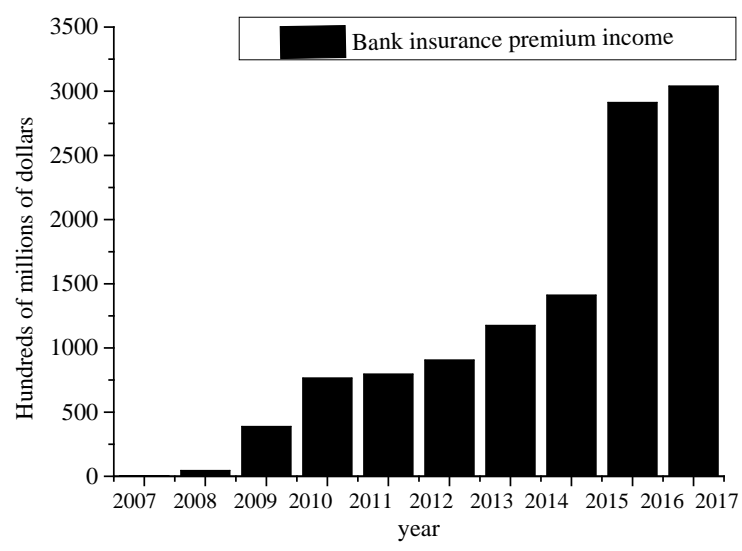

Figure. 2 2007-2017 National bank insurance premium income.

\subsection{Formulation and improvement of bank insurance development strategy in China}

The development of bank insurance in China has achieved remarkable results, but there are still some problems in practice. Therefore, for the sustained and stable development of China's bank insurance, it should: Improve the understanding of bank insurance and change the business philosophy; promote the integration of corporate culture and promote customer relationship management; deepen cooperation level, collaborative product and channel innovation; establish and improve incentive and restraint mechanisms; scientifically formulate talent strategy and cultivate complex talents; deepen the development and application of information technology and improve the construction of customer management systems. 


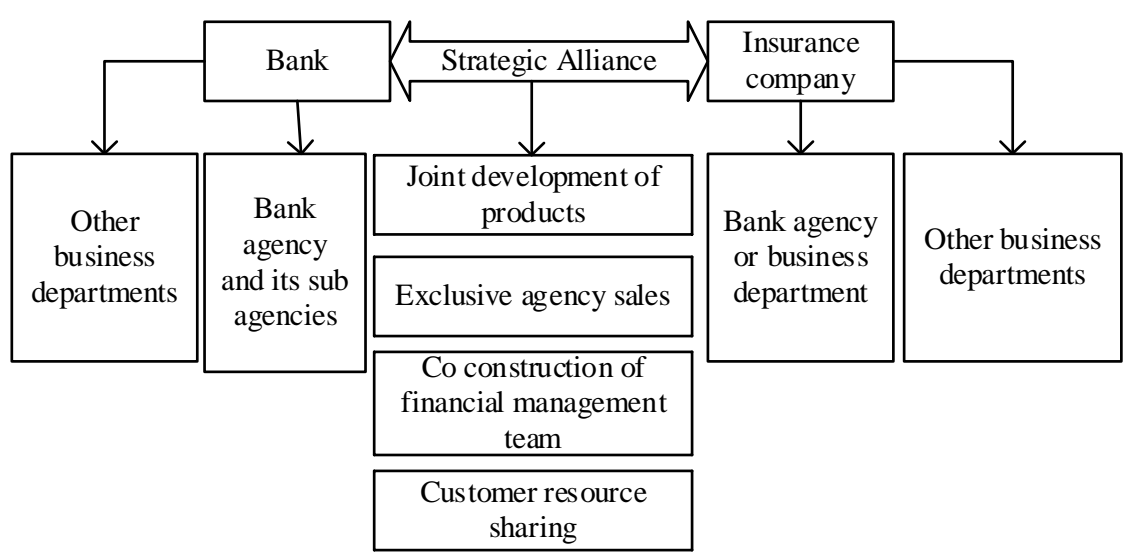

Figure. 3 The model of the strategic alliance of the bank insurance

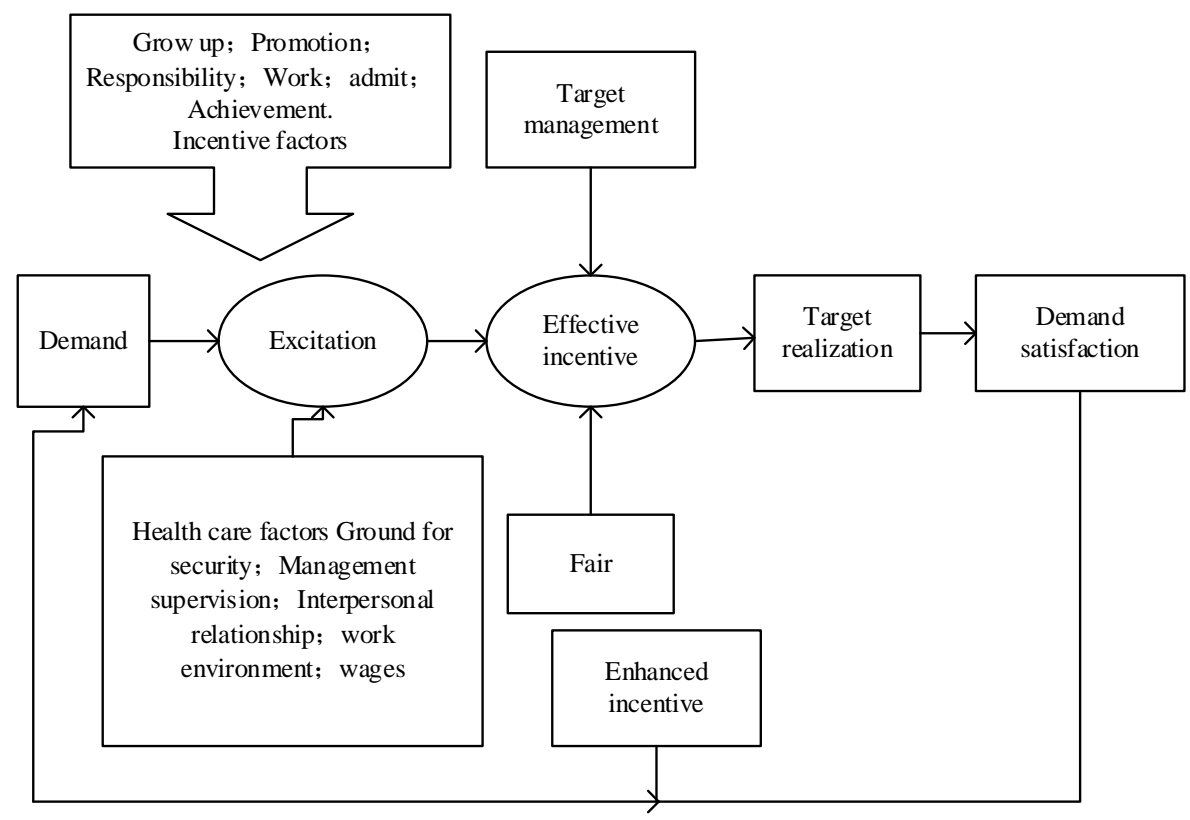

Figure. 4 Incentive mechanism model in the management of bank insurance channel

\section{Conclusion}

This study summarizes the history and experience of international bank insurance development, external environmental factors including the legal environment, regulatory system, and taxation policies have greatly affected the development of bank insurance. In the transitional stage of further deepening the development of bank insurance in China, we should create a relaxed institutional environment and promote the deep integration of banks and insurance institutions; promote the construction of relevant legislation and improve the financial legal system; strengthen the coordination and cooperation between the bancassurance institutions; give play to the supervisory and guiding role of industry self-discipline; implement corresponding tax incentives. Through the continuous improvement of these external environments, it will promote the sustained, rapid and healthy development of China's bank insurance.

\section{References}

[1] Moreno-Benito, M., Frankl, K., Espuña, A., \& Marquardt, W. A modeling strategy for integrated batch process development based on mixed-logic dynamic optimization. Computers \& Chemical Engineering, 2016, (94), pp.287-311.

[2] Watson, D. P., Young, J., Ahonen, E., Xu, H., Henderson, M., \& Shuman, V., et al. Development 
and testing of an implementation strategy for a complex housing intervention: protocol for a mixed methods study. Implementation Science, 2014, 9(1), pp. 1-10.

[3] Su, C., Chen, Y., Wang, W., Ran, R., Shao, Z., \& Jc, D. D. C., et al. Mixed fuel strategy for carbon deposition mitigation in solid oxide fuel cells at intermediate temperatures. Environmental Science \& Technology, 2014, 48(12), pp.7122-7127.

[4] Xianyang Jiang, Lei Shen, Xiaorong Xu, Jianrong Bao, Yu-Dong Yao, \& Zhijin Zhao. Power allocation optimisation for high throughput with mixed spectrum access based on interference evaluation strategy in cognitive relay networks. Iet Communications, 2016, 10(12), pp.1428-1435.

[5] Ott, J. P., \& Hartnett, D. C. Bud bank dynamics and clonal growth strategy in the rhizomatous grass, pascopyrum smithii. Plant Ecology, 2015, 216(3), pp.395-405.

[6] Slagsvold, T., Johannessen, L. E., \& Bo, T. H. Effects of social rearing conditions on song structure and repertoire size: experimental evidence from the field. Animal Behaviour, 2015, 72(1), pp.83-95. 